\title{
Policy Analysis Implementation of 2013 Thematic Learning Curriculum (Case Study in Primary School St. Thomas Medan)
}

\author{
Johannes Sohirimon Lumbanbatu \\ STP St. BONAVENTURA KAM- \\ Delitua Medan, \\ johlumbanbatu28@gmail.com
}

\author{
Zainuddin \\ Professor at Universitas Negeri Medan \\ Medan, Indonesia
}

\author{
Din Oloan Sihotang \\ Lecturer at Politeknik IT \& B Medan \\ Medan, Indonesia
}

\begin{abstract}
- the purpose of this study was to determine the condition of students in the implementation of the 2013 curriculum in thematic learning at St. Thomas Elementary School in Medan in 2018/2019 academic year, to know the condition of teachers in the implementation of thematic learning 2013 curriculum, to know the conditions of the implementation of the 2013 thematic learning curriculum, and to understand teacher understanding Elementary school Thomas Medan on the 2013 curriculum. This type of research is qualitative. The evaluation model used by Models Stake Countenance. This model emphasizes two main things, namely describing and judging. The main thing is obtained through the stages of evaluation, namely the stage of Final Implementation (Antecedent), Process Stage (Transaction) and Stage results (Outcomes). Population and sample of 4 student classes (parallel classes 4 and 5) with 1 headmaster, 30 teachers. From the results of the study the theory found several conclusions that; a) The antecedent stage, namely: the condition of the student is not fully in accordance with the standard with a percentage of $55.9 \%$ and sufficient category; the condition of the teacher is not fully in accordance with the standard with a percentage of $56.8 \%$, and is categorized sufficient; the teachers understanding of the curriculum is not fully in accordance with the standard with a percentage of $63.2 \%$, but has been categorized well; the condition of learning planning is not yet fully in accordance with the standards of $85 \%$, but has been categorized very well; b) Transaction stage; the implementation of scientific based integrative thematic learning has been categorized very well with a percentage of $91 \%$; the implementation of thematic assessments is not yet fully in accordance with the standards with a percentage of $54.3 \%$ and sufficiently categorized, and c) Stage of outcomes Authentic assessment results have met very good standards and categories with a percentage of $100 \%$.
\end{abstract}

Keywords- Policy, curriculum, learning, thematic, evaluation

\section{INTRODUCTION}

Since the 2013/2014 academic year the K-13 national curriculum has been implemented in Indonesia. The application of the 2013 Curriculum at the elementary, junior and senior high school levels was based on Ministerial Regulation Number 81a on the implementation of the 2013 curriculum. At the beginning of the 2013 Curriculum, its implementation was still limited because it was only applied in pilotting schools designated by the government that met the requirements and selective. At the Primary School level there are only 44,609 schools (30\%) from all elementary schools in Indonesia that implement the 2013 Curriculum. Expectations from the government, in the 2014/2015 school year, grade I, II, IV and V elementary schools have implemented the 2013 Curriculum. Since the 2015/2016 academic year all elementary school levels have implemented the 2013 curriculum. Although in practice it has not yet been realized according to plan.

The enactment of the 2013 curriculum is a renewal in the education system. The renewal in the education system is adjusted to the demands on aspects of life. This is in accordance with the explanation of the National Education System Law number 20 of 2003 which states that demands on all aspects of life give rise to demands for the renewal of the education system [1].

The implementation of education in Indonesia currently refers to the 8 National Education Standards (SNP). SNP becomes the basic reference standard that must be achieved in the effort to provide education. In developing the 2013 curriculum, standards in the SNP were still considered to be met. Related to internal challenges stemming from the development of the Indonesian population, improvements in education must be able to facilitate Indonesia's human resources at productive age into competent human resources in the face of the changing times.

The 2013 Curriculum Development also pays attention to challenges that come from outside (external). External challenges include: External challenges faced by the world of education, among others, relate to the challenges of the future, competencies needed in the future, community perceptions, knowledge and pedagogical developments, and various negative phenomena that arise [1].

The preparation of the curriculum begins by setting Graduates Competency Standards based on student readiness, national education goals, and needs. Next determine the curriculum which consists of the basic curriculum framework and curriculum structure. The syllabus is prepared from the center, not by the education unit and the teacher. Teachers are 
given more opportunities to develop the learning process. So the teacher is not burdened with the tasks of preparing the syllabus

In the implementation of the new curriculum, several factors such as school resources, the community, principals, teachers, and external factors must be considered and prepared optimally. The [2] explains these five factors: school district/school environment (related to school conditions, facilities, and supporting infrastructure), community/community (related to community support), principal/principal (related to management and leadership), teacher (related to response, support, teacher participation), and external factors / external factors (related to support from government/stakeholders/private sector).

In the 2018/2019 school year at elementary school. St. Thomas Medan, who was appointed by the government as a pilotting school implementing the 2013 curriculum. Its implementation is still limited and is only carried out for grades I and IV. In the preparation stage, not all teachers are skilled in operating IT so as to hamper fluency in the implementation of tasks such as the creation of lesson plans, value processing, using multimedia learning media, and others. Some of the material in Student Books in grades I and IV is not in order of degree of difficulty because they are arranged based on themes. Learning materials on student books and teacher books are very minimal so they must use relevant companion books.

TABLE I. RESULT OF SURVEY

\begin{tabular}{|l|l|}
\hline \multicolumn{1}{|c|}{ Researcher } & \multicolumn{1}{|c|}{ Research Findings Point } \\
\hline $\begin{array}{l}\text { Research } \\
\text { Johannes (2019) }\end{array}$ & $\begin{array}{l}\text { the problems in the implementation of the 2013 } \\
\text { curriculum are among others not good in the } \\
\text { stages of preparation, implementation, and } \\
\text { evaluation / evaluation. }\end{array}$ \\
\hline Erni [3] & $\begin{array}{l}\text { implementation goes well with the good } \\
\text { category, the component input syllabus aspects } \\
\text { and the teacher's lesson plan are prepared based } \\
\text { on applicable regulations, and the teacher } \\
\text { performance component has a good category }\end{array}$ \\
\hline
\end{tabular}

\begin{tabular}{|l|l|}
\multicolumn{1}{|c|}{ TABLE 2. THEORY ANALYSIS } \\
\hline $\begin{array}{l}\text { Researcher } \\
\text { Grindle S. }\end{array}$ & $\begin{array}{l}\text { Values point } \\
\text { Successful implementation is influenced by two } \\
\text { large variables, namely the content of the policy } \\
\text { (content of policy) and the implementation } \\
\text { environment (context of implementation). }\end{array}$ \\
\hline $\begin{array}{l}\text { Edward III in } \\
{[4]}\end{array}$ & $\begin{array}{l}\text { policy implementation is influenced by four } \\
\text { variables, namely: a) Communication, resources, } \\
\text { disposition, birchration and implementation. } \\
\text { From the expert's perspective on public policy, } \\
\text { the success of implementing a policy can be seen } \\
\text { from the point of view of the success or failure of } \\
\text { the implementation of the policy. }\end{array}$ \\
\hline
\end{tabular}

On the basis of this, the study was conducted under the title Analysis of Implementation of the 2013 Curriculum Thematic Integrated Learning Field Study of Catholic Religion Class I \& Iv Private Elementary School St. Thomas Medan Academic Year 2018/2019

\section{LITERATURE REVIEW}

\section{A. K-13 Elementary School Curriculum with Thematic Learning}

The term curriculum is derived from the Greek curir, meaning "runner" and curere which means "place to race". Curriculum means the distance a runner must go from start to finish to get an award. In the world of education, distance is defined as an educational program that contains subjects.

While the [5] author explains: "The curriculum represents a set of desired goals or values that are activated through a development process and culminates in successful learning experiences for students".

Next, the [2] writer states that education reform must pay attention to various factors such as (1) characteristics of change, (2) local character, and (3) external factors.

Characteristics of change include the needs of teachers and students in learning activities, the clarity of the educational innovation process, the complexity associated with the level of individual responsibility involved in the implementation process, the quality of the materials or resources used in the application of innovation.

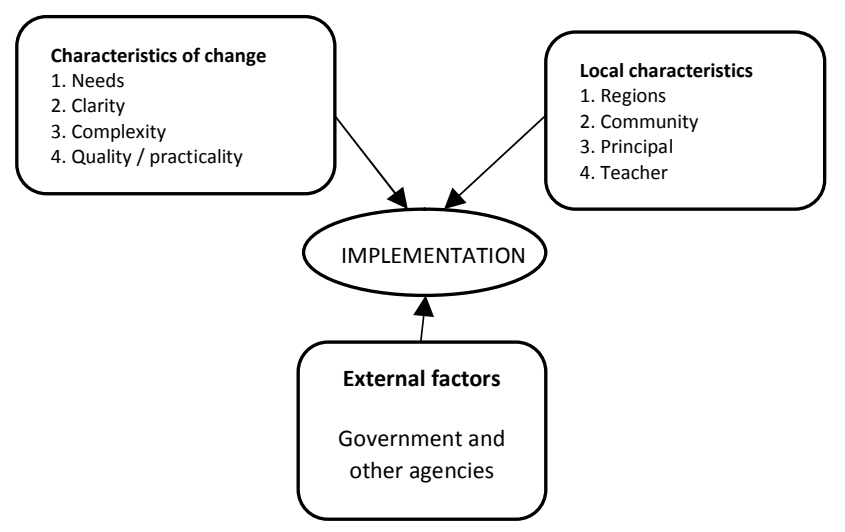

Fig 1. Schematic Factors affecting curriculum implementationSource[2]

\section{B. Characteristics of the 2013 Curriculum}

Based on [6] concerning Elementary Curriculum, the 2013 Curriculum for Elementary Schools is designed with the following characteristics:

- Develop a balance between developing spiritual and social attitudes, curiosity, creativity, collaboration with intellectual and psychomotor abilities;

- Schools are part of the community that provides a planned learning experience where students apply what is learned in school to the community and use the community as a learning resource;

- Develop attitudes, knowledge, and skills and apply them in various situations in schools and communities; 
- Give enough free time to develop a variety of attitudes, knowledge, and skills;

- Competencies are expressed in the form of core class competencies which are further detailed in the basic competencies of the subject;

- Class core competencies become organizing elements of basic competencies, where all basic competencies and learning processes are developed to achieve the competencies expressed in core competencies;

- Basic competencies are developed based on the principle of accumulative, mutually reinforcing and enriched between subjects and levels of education (horizontal and vertical organizations).

\section{Thematic Learning}

Centered thematic learningaccording to[7]namely : The integrated curricular model represent a cross disciplinary approach similar to the shared model. The integrated model major blends the four major disciplines by setting curricular priorities in each and finding the overlapping skills, concepts, an attitudes in all four. As in the shared model, the integration is aresult of sifting ideas out of the subject matter content, not laying idea over the subject as in the webbed themes approach. The integration sprouts from within the various disciplines and matches are made among them as commonalities emerge.

\section{Principles of integrated thematic learning}

The principles underlying the integrated Thematic Learning according to the Ministry of Education and Culture [1] include the following:

- Themes should not be too broad and can be easily used to integrate many fields of study, subjects, or scientific disciplines.

- The chosen theme can provide provisions for students to learn more.

- Themes are adjusted to the level of student development.

- The theme must be able to accommodate most children's interests,

- Themes must consider authentic events that occur within the learning period

- Themes chosen according to the applicable curriculum

- The theme chosen is according to the availability of learning resources.

\section{H. Public Policy Concepts}

The [7] writer states that there are several theories developed about Policy Implementation, namely; George C. Edward III, Merilee S. Grindle, Daniel A. Mazmanian and Paul A. Sabatier, van Meters and van Horn, Cheema and Rondinelli, and David L. Weimer and Aidan R. Vining.

Merille S. Grindle Theory in [5] stated that success of implementation according to Merilee S. Grindle is influenced by two major variables, namely the policy content (content of policy) and the implementation environment (context of implementation). The contents of this policy include: (1) The extent to which the interests of the target group or target group are contained in the contents of the policy, (2) The type of benefits received by the target group, (3) The extent of desired changes in a policy, (4) what is the location a program is appropriate, (5) whether a policy has specified the implementor in detail, (6) whether a program is supported by adequate resources.

\section{METHODOLOGY}

This research uses qualitative research. The evaluation model used is the Stake Countenance Model. This model emphasizes two main things, namely describing and judging. These two main points are obtained through evaluation stages, namely: (1) Final Antecedent Phase, (2) Transaction stage, which is a description of curriculum implementation, and (3) Outcomes stage

The results of the observations will be compared with the standards in the judgment column to determine their suitability. If there is no conformity with the existing standards, then judgments are related to the implementation of the 2013 Curriculum.Population and sample of 4 student classes (parallel classes 4 and 5) with 1 headmaster, 30 teachers. Data collection techniques using non-test techniques using questionnaire, observation, and documentation techniques.

\section{RESULTS AND DISCUSSION}

Research on evaluating the implementation of the 2013 I \& IV elementary school curriculum in St. Thomas Medan, the 2017/2018 school year emphasizes two main things, namely description and judgments. These two things are obtained through portrayal of the antecedent, transaction, and stage outcomes.

The condition of the teacher's understanding of the 2013 curriculum

Conditions related to teacher understanding of the 2013 curriculum consist of syllabus studies, analysis of teaching materials, and completeness of curriculum documents. For the presentation of data on the condition of teacher understanding of the 2013 curriculum presented in the following table 3 :

TABLE 3. CONDITIONS FOR TEACHER UNDERSTANDING OF THE 2013 CURRICULUM

\begin{tabular}{|c|c|c|c|c|}
\hline No & Interval Score & Chategories & Jumlah & $\%$ \\
\hline 1. & $\geq 87,4$ & Very Good & 6 & $13,3 \%$ \\
\hline 2. & $78,6-87,3$ & Good & 22 & $48,9 \%$ \\
\hline 3. & $69,8-78,5$ & Enough & 9 & $20 \%$ \\
\hline 4. & $<69,8$ & Worse & 8 & $17,8 \%$ \\
\hline \multicolumn{3}{|r|}{ Jumlah } & 45 & $100 \%$ \\
\hline \multicolumn{2}{|l|}{ Good Percentace } & $62,2 \%$ \\
\hline \multicolumn{2}{|l|}{ Worse Percentace } & $37,8 \%$ \\
\hline
\end{tabular}

The mean / mean for the overall score of 78.6 with a standard deviation of 8.8. Conditions related to teacher understanding of the 2013 curriculum, as many as 6 teachers $(13.3 \%)$ were categorized very well, 22 teachers $(48.9 \%)$ 
categorized well, 9 teachers $(20 \%)$ categorized as poor, and 8 teachers $(17,8 \%)$ very poorly categorized.

TABLE 4.DATA ON THE RESULTS OF THE EVALUATION OF THE 2013 CURRICULUM

\begin{tabular}{|c|c|c|c|c|c|}
\hline \multirow{2}{*}{ Step } & \multirow{2}{*}{ Aspect } & \multicolumn{2}{|c|}{$\begin{array}{c}\text { Description } \\
\text { Matrix }\end{array}$} & \multicolumn{2}{|c|}{ Judgment matrix } \\
\hline & & Intents & $\begin{array}{c}\text { Obervat } \\
\text { ions }\end{array}$ & $\begin{array}{c}\text { Standar } \\
\text { ds }\end{array}$ & Judgments \\
\hline \multirow{7}{*}{$\begin{array}{c}\text { Begining } \\
\text { (Anteced } \\
\text { ent) }\end{array}$} & \multirow{2}{*}{$\begin{array}{l}\text { student } \\
\text { condition }\end{array}$} & $\begin{array}{l}\text { Readin } \\
\text { ess }\end{array}$ & $50,7 \%$ & $100 \%$ & $\begin{array}{c}\text { In } \\
\text { considerati } \\
\text { on }\end{array}$ \\
\hline & & $\begin{array}{l}\text { Active } \\
\text { ness }\end{array}$ & $56,8 \%$ & $100 \%$ & $\begin{array}{c}\text { In } \\
\text { considerati } \\
\text { on } \\
\end{array}$ \\
\hline & \multirow{5}{*}{$\begin{array}{l}\text { Teachers } \\
\text { condition }\end{array}$} & $\begin{array}{l}\text { Acade } \\
\text { mic } \\
\text { qualific } \\
\text { ation } \\
\end{array}$ & $84,4 \%$ & $100 \%$ & $\begin{array}{c}\text { In } \\
\text { considerati } \\
\text { on }\end{array}$ \\
\hline & & $\begin{array}{l}\text { Pedago } \\
\text { gic } \\
\text { compet } \\
\text { ency } \\
\end{array}$ & $60 \%$ & $100 \%$ & $\begin{array}{c}\text { In } \\
\text { considerati } \\
\text { on }\end{array}$ \\
\hline & & $\begin{array}{l}\text { Person } \\
\text { nel } \\
\text { compet } \\
\text { ency }\end{array}$ & $66,7 \%$ & $100 \%$ & $\begin{array}{c}\text { In } \\
\text { considerati } \\
\text { on }\end{array}$ \\
\hline & & $\begin{array}{c}\text { Social } \\
\text { compet } \\
\text { ency }\end{array}$ & $55,5 \%$ & $100 \%$ & $\begin{array}{c}\text { In } \\
\text { considerati } \\
\text { on }\end{array}$ \\
\hline & & $\begin{array}{c}\text { Profess } \\
\text { ional } \\
\text { Compe } \\
\text { tency } \\
\end{array}$ & $57,8 \%$ & $100 \%$ & $\begin{array}{c}\text { In } \\
\text { considerati } \\
\text { on }\end{array}$ \\
\hline \multirow{2}{*}{$\begin{array}{l}\text { Process } \\
\text { (Transact } \\
\text { ion) }\end{array}$} & $\begin{array}{l}\text { Learning } \\
\text { action }\end{array}$ & $\begin{array}{c}\text { Impel } \\
\text { mentati } \\
\text { on }\end{array}$ & $90 \%$ & $100 \%$ & $\begin{array}{c}\text { In } \\
\text { considerati } \\
\text { on } \\
\end{array}$ \\
\hline & Thematic & $\begin{array}{c}\text { Authen } \\
\text { tic } \\
\text { judgme } \\
\text { nt }\end{array}$ & $53,3 \%$ & $100 \%$ & $\begin{array}{c}\text { In } \\
\text { considerati } \\
\text { on }\end{array}$ \\
\hline Outcome & $\begin{array}{l}\text { Thematic } \\
\text { Assessment } \\
\text { Results }\end{array}$ & $\begin{array}{l}\text { Authen } \\
\text { tic } \\
\text { Assess } \\
\text { ment } \\
\text { Results }\end{array}$ & $100 \%$ & $100 \%$ & $\begin{array}{c}\text { No } \\
\text { considerati } \\
\text { on }\end{array}$ \\
\hline
\end{tabular}

Source: Data Analysis Results

\section{A. Antecedent stage}

The results of the analysis of the preliminary stage which includes the condition of students, the condition of the teacher, the condition of infrastructure, the teacher's understanding of the 2013 curriculum, learning planning are described as follows:

\section{1) Student condition}

The condition of the categorized students is very good and good at $54.9 \%$. Difference with standard is $45.1 \%$. The condition of the students related to the readiness of students to take part in the learning which is included in the good category is $50.7 \%$. Difference with standard is $49.3 \%$. The condition of the students related to the activity of students in participating in learning included a good category of $56.8 \%$. Difference with standard is $43.2 \%$. Data of students with good categories is more than the data of students in the less category.

\section{2) Teacher's condition}

The conditions of the teacher include academic qualifications, pedagogical competencies, personality competencies, social competencies, and professional competencies. The overall condition of the teacher included an excellent category of $57.8 \%$, and a category of less than $42.2 \%$.

\section{B. Transaction stage}

The process stage consists of implementing learning and implementing authentic assessments. The learning process consists of 10 indicators, namely a) Applying apperception and motivation; b) Explain competencies and planned activities; c) Mastering the material being taught; d) Implement an educational learning strategy; e) Applying a scientific approach; f) Implement integrated thematic learning; g) Utilizing learning resources / media in learning; h) Triggering / maintaining the involvement of students in learning; i) Ending learning effectively; and j) Using the right and proper language in learning. The conditions related to the implementation of learning obtained very good category data $30 \%$, 60\% good category, and 10\% less category. Data included in the good category as much as $90 \%$.

\section{Results phase (outcomes)}

The results stage is the result of authentic assessment which includes the values of aspects of knowledge, skills and attitudes[8]. Data of authentic assessment results are categorized as very good $30 \%$, good categories are $70 \%$, categories are less $0 \%$, and categories are very less $0 \%$.

Gaps also occur between transactions (processes) and outcomes (results). Transaction (process) with a percentage of $72 \%$ while outcomes (results) with a percentage of $100 \%$. The gap in both stages has increased by $28 \%$. The learning process at the transaction stage observed during the observation is not yet $100 \%$ fulfilled, but at the yield stage (oucomes) it has increased. This means that the process that occurs goes well on the absorption of students so that learning outcomes (outcomes) can be fulfilled $100 \%$.

\section{CONCLUSION}

From the results of the study, it can be concluded that:

1) Antecedent stage (introduction)

- The condition of students viewed from the aspect of readiness to follow the lessons and activeness during learning is not fully in accordance with the standard with a percentage of $54.9 \%$ and enough categories.

- The condition of the teacher seen from the aspect of academic qualifications, pedagogic competence, personality competence, social competence, and professional competence is not yet fully in accordance with the standard with a percentage of $57.8 \%$, and is categorized sufficient.

- Teachers' understanding of the curriculum is not fully in accordance with the standard with a percentage of $62.2 \%$, but has been categorized well. 
- The condition of learning planning is not yet fully in accordance with the standard of $85 \%$, but has been categorized very well.

\section{2) Transaction stage}

- The implementation of scientific based integrative thematic learning has been categorized very well with a percentage of $90 \%$.

- The implementation of authentic assessments is not fully in accordance with the standards with a percentage of $53.3 \%$ and sufficiently categorized.

Stage outcomes

The results of the authentic assessment already meet the standards and are categorized very well with a percentage of $100 \%$.

\section{ACKNOWLEDGMENT}

This research was support by STP St. Bona Ventura KAM Medan by supporting funds. And special thanks to St. Thomas Medan management in supporting this reaserch. We would also like to show our gratitude to the lecturer at Universitas Negeri Medan for sharing their pearls of wisdom with us during the course of this research, and we AISTEEL reviewers for their so-called insights.

\section{REFERENCES}

[1] Kemdikbud. (2013). Materi pelatihan guru implementasi kurikulum 2013 SD kelas IV. Jakarta: Dirjen Dikdasmen Kemdikbud.

[2] Fullan, M.G. (2007). School development: the new meaning of educationalchange. New York: Teachers College Press.

[3] Erni (2013). Evaluasi Pembelajaran Tematik di SDN 158 Watallipu Kecamatan Soppeng.

[4] AG. Subarsono. 2005. Analisis Kebijakan Publik; Konsep, Teori dan Aplikasi. Yogyakarta : Pustaka Pelajar

[5] Wiles, J. \& Bondi. 2007. Supervision A Guide to Practice. Second Edition. London:

[6] Permendikbud No 67 tahun 2013 tentang Kurikulum SD

[7] Fogarty, R. (2009). The mindful school how to integrate the curricula $\left(3^{\text {rd }}\right.$ ed). Palatine. Skylight Publishing

[8] Schunk, Dale. H. 2009. Learning Theories: An Educational Perspectives, 6th Edition. New York: Pearson Education Inc. 